\title{
特集 少子高齢時代の交通インフラ【論説】
}

\section{整備新幹線による新たな交通体系の構築と \\ ネットワーク効果の進展}

Effects of Expansion on the Current Bullet Train Transportation Network

Haruo ISHII : Toyo University

石井 晴夫*

\section{1. 規制緩和による交通政策の変化}

わが国における高速道路・空港・港湾などの交 通社会資本の建設・整備は, 主として国及び地方 公共団体からの歳出（税金）と利用料収入に依存 してきた。これに対し，鉄道整備，とりわけ民間 鉄道の場合には，自らが鉄軌道を建設すると同時 に, 維持・管理・運営も基本的には自社で行うこ ととされており, 鉄道インフラの整備に対する国 からの補助等は欧米諸国と比べても相対的に少な かった1。つまり, 鉄道事業においては長年, イン フラの投資資金をすべて運賃収入で回収するとい う「フルコスト主義」が採用されてきた。しかし， 人口減少時代を迎えて輸送人員も大幅に伸び悩ん でいる今日においては, 従来の伝統的な鉄道施設 整備手法も限界がきているといえよう2。

他方, 2000年 3 月には「鉄道事業法の一部を改 正する法律」が施行され, 参入 ·退出規制が緩和 されるとともに, 運賃も総括原価方式の下での上 限価格制等が法定化された。このうち参入規制に ついては, 従来の需給調整規制を含む免許制が廃 止され，路線ごとに事業の実現可能性や継続性, さらには安定性や輸送の安全性等を審査する許可 制が採用された。また，退出規制については，従 来の許可制を原則一年前の事前届出制に改められ,
鉄道事業者は不採算路線等からの撤退が容易と なった。なお，退出に際しては運輸大臣（現在は 国土交通大臣）が退出後の沿線地域における交通 の利便確保に関し, 関係地方公共団体等から意見 を聴取することとしている。

また，運賃規制においては，1997年以来運用で 行ってきた上述の上限価格制の下での事前届出制 が法律で明文化された。さらに，乗り継ぎ等の利 便性の向上を図るために，鉄道施設接続に関し従 来の改善命令に先立つ自主的ルールとして, 鉄道 事業者間の努力を求めると同時に, 運輸大臣（当 時）の裁定・针告について, 一定のルールが設け られることとなった。なお, 貨物鉄道分野におい ては，2002年 6 月に需給調整規制や運顀の事前規 制を廃止する鉄道事業法の一部改正が行なわれ, 貨物鉄道についても規制緩和が実施されている。

このような状況下において, わが国では2012年 6 月に整備新幹線の未着工区間の工事が認可され, 新たな交通体系の構築が図られることになった。 整備新幹線の建設によって, 新しい高速交通ネッ トワークの構築が実現されることから, 本稿では, 整備新幹線の機能と役割についてレビューすると ともに, その意義と今後の課題等についても論述 することとする。さらに, 整備新幹線の開業に伴っ て分離される並行在来線の現状やJR貨物の調整

石井 晴夫* (いしい はるお) 東洋大学経営学部教授

1 鉄道整備助成費が政府の公共事業費の一項目として認められたのは1994年のことであった。金本義嗣・山内弘隆編 (1995) 『公的規制と産業(4)交通』NTT出版, p.132を参照。

2 石井晴夫 (1999)『交通ネットワークの公共政策(第 2 版)』中央経済社, p.135を参照。 
措置についても考察することとする。

\section{2. 整備新幹線の定義と整備手法}

周知のとおり，わが国で最初の新幹線は，国鉄 時代の1964年10月 1 日に開通した東京〜新大阪間 を結ぶ東海道新幹線である。続いて1970～80年代 にかけて, 山陽新幹線や東北新幹線, 上越新幹線 が次々と着工していった。一方, 整備新幹線とは 1973年 (昭和48年)に全国新幹線鉄道整備法第 7 条 に基づいて, 整備計画が決定された新幹線 5 路線 のことをいい, 同法では東北新幹線（盛岡市〜青 森市), 北海道新幹線（青森市～札幌市), 北陸新 幹線 (東京都〜大阪市), 九州新幹線・鹿児島ルー 卜 (福岡市〜鹿児島市), 九州新幹線・長崎ルート （福岡市〜長崎市）の各路線が取り上げられてい $ろ^{3}$ 。

整備新幹線として初めて開通したのは, 1997年 10月 1 日の北陸新幹線高崎〜長野間 $(117 \mathrm{~km})$ で ある。これは北陸新幹線の一部区間ではあるが, 一般的に「長野新幹線」と呼ばれている。その後, 2010年12月に八戸〜新青森，2011年 3 月に博多〜 新八代間が開業し, 東北新幹線と九州新幹線の鹿 児島ルートはすでに全線が開通している。従って, 現在工事中ないし認可を受けているのは，2004年 12 月の政府・与党申合世「整備新幹線の取扱いに ついて」及び2011年12月の政府・与党確認事項 「整備新幹線の取扱いについて」に基づいて工事実 施計画の認可を受けた 3 路線 6 区間（延長約 $780 \mathrm{~km})$ である。その内訳は，すでに工事が着工 している区間が北海道新幹線(新青森〜新函館間), 北陸新幹線（長野～金沢間), 九州新幹線・長崎 ルート（武雄温泉〜諫早間）であり，2012年 6 月 29日に新たに認可された対象区間は, 北海道新幹 線 (新函館～札幌間), 北陸新幹線 (金沢〜敦賀間), 九州新幹線・長崎ルート（諫早〜長崎間）の 3 区 間となっている。
整備新幹線は, 新幹線として走行する主たる区 間を時速 $200 \mathrm{~km}$ 以上の高速で走行できる幹線鉄道 のことであり，新幹線鉄道による全国的な鉄道 ネットワークの整備を図ることによって，国土の 均衡ある発展を図り，国民経済や地域の活性化等 に資することがその役割として要請されている。 また, 整備新幹線の整備方式は, 鉄道建設・運輸 施設整備支援機構が新幹線の施設を建設, 保有し, 営業主体であるJRに対して施設を貸し付ける「上 下分離方式」により運営されている。財源につい ては，貸付料収入を充てた残りの部分について, 国が 3 分の 2 , 地方公共団体が 3 分の 1 を負担す ることとしている。図 1 は, 上下分離方式による 整備新幹線の整備手法を図で説明したものである。

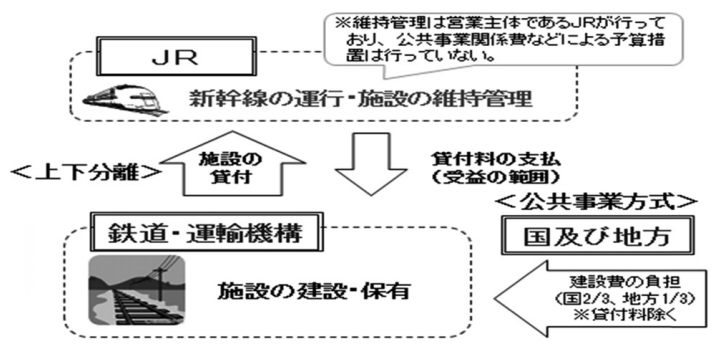

図 1 上下分離方式による整備新幹線の整備手法 出典）国土交通省の資料により作成。

\section{3. 整備新幹線に関わる検討内容}

\section{(1) 政府・与党による整備新幹線の取扱い}

2011年12月26日の「整備新幹線の取扱いについ て」（政府·与党確認事項）では，これまでの整備 新幹線問題検討会議等における方針等や検討結果, 及び「整備新幹線の未着工区間の取扱いにかかる 申し入れ」(平成23年12月21日) を踏まえ, 今後の 整備新幹線の取扱いについて基本的かつ重要な事 項が確認されている。

まず「基本的な考え方」として, 第 1 は, 財政 規律に配慮して公共事業関係費やそれに伴う地方

\footnotetext{
3 東海道新幹線, 山陽新幹線, 東北新幹線 (東京〜盛岡間), 上越新幹線, 山形新幹線, 秋田新幹線は, 整備新幹線の範疇 には含まれない。
} 
負担に過度に依存せず，整備新幹線の貸付料収入 を, 必要に応じた前倒しも含めて建設財源に活用 する。第 2 は，財源を有効活用する観点から新た な区間の事業ペースを調整し, 多重的な輸送体系 の確保等を配慮しつつ, 各線区の適切な事業区間 や開業時期を設定する。第 3 は, 安定的な財源見 通しを確保した上で，いわゆる「着工 5 条件」の 残余条件（収支採算性，投資効果，営業主体であ るJRの同意, 並行在来線の経営分離についての沿 線自治体の同意）を満たした上で, さらに, 各線 区の課題(「整備新幹線の未着工区間等の取扱いに ついて」(平成 22 年 8 月 27 日整備新幹線問題検討会 議)に揭げるものをいう。以下同じ。）について対 応が示されていることを確認した際は, 新たな区 間の認可・着工を行う。第 4 は, 厳しい財政制約 を踏まえ, 引き続き, 建設主体の自主財源の確保 のため努力を継続する，というものである4。

こうした基本的な考え方を踏まえ, 新たな着工 区間については，その効果や採算性を十分に吟味 する必要がある。以上のことから, 収支採算性と 投資効果を改めて確認することとし，その上で,
以下の「認可・着工に先立ち満たすべき条件」が 整い, かつ, 各線区の課題について対応が示され ていることを確認した区間から，所要の認可等の 手続きを経て着工することとしている。

北海道新幹線（新函館～札幌間）について, 認 可・着工に先立ち満たすべき条件としては, 営業 主体であるJR北海道の同意, 並びに並行在来線の 経営分離に関する沿線地方自治体の同意が必要で ある。また，想定される開業時期を新青森〜新函 館間の開業から概ね 20 年後としている ${ }^{5}$ 。次に, 北 陸新幹線（白山総合車両基地～敦賀間）について は, 北海道新幹線と同様に営業主体であるJR西日 本の同意, 並びに並行在来線の経営分離に関する 沿線地方自治体の同意が必要であるとし, 想定さ れる開業時期を長野〜白山総合車両基地間の開業 から概ね10年後を見込んでいる 6 。さらに，九州 新幹線については, 営業主体であるJR九州の同意 が必要であるとし, 想定される開業時期を武雄温 泉〜長崎間を一体として, 諫早〜長崎間の着工か ら概ね 10 年後を想定している7。

一方, 整備新幹線全線の早期整備に向けての全

表 1 整備新幹線に関わる主な政府・与党申合せの経過

\begin{tabular}{|c|c|}
\hline 1989 年 1 月 & 「整備新幹線の取扱いについて」（政府－与党申合せ） \\
\hline 1990 年 12 月 & 「整備新幹線着工等について政府‧与党申合せ」 \\
\hline 1996 年 12 月 & 「整備新幹線の取扱いについて政府与党合意」 \\
\hline 2009 年 12 月 & $\begin{array}{l}\text { 「整備新幹線の整備に関する基本方針」(平成 } 21 \text { 年 } 12 \text { 月 } 24 \text { 日） } \\
\text { 「当面の整備新幹線の設備方針」（整備新幹線問題検討会議） }\end{array}$ \\
\hline 2010 年 8 月 & 「整備新幹線の未着工区間等の取扱いについて」(整備新幹線検討会議) \\
\hline 12 月 & 「整備新幹線に関する今後の対応について」(整備新幹線検討会議) \\
\hline $\begin{array}{r}2011 \text { 年 } 5 \text { 月 } \\
\text { 及び } 6 \text { 月 }\end{array}$ & $\begin{array}{l}\text { 「国鉄清算事業団債務処理法改正案に対する付帯決議」 } \\
\text { (衆議院・参議院） }\end{array}$ \\
\hline 2011 年 12 月 & $\begin{array}{l}\text { 「整備新幹線の取扱いについて」(平成 } 23 \text { 年 } 12 \text { 月 } 26 \text { 日、政府·与党 } \\
\text { 確認事項) }\end{array}$ \\
\hline
\end{tabular}

出典）政府資料による。

\footnotetext{
4 詳しくは，国土交通省ホームページ『整備新幹線の現状』を参照されたい。

$<$ http://www.mlit.go.jp/common/000224502.pdf>

5 青函共用走行区間の最高速度は当面 $140 \mathrm{~km} / \mathrm{h}$ とし，北海道内に㧍ける最高設計速度は $260 \mathrm{~km} / \mathrm{h}$ とする。

6 敦賀以西の整備のあり方については, 以下のとおり整理することとする。財源の限界等から新たな 3 区間に係る事業が完 了するまでの間の整備は難しいが, 敦賀まで開業することで, 京阪神の鉄道ネットワークへの接続, 幹線交通の多重化等 の機能を果たし得ることから，北陸を経由して関東・関西を結ぶ新幹線ネットワークが概成すると言える。その際のネッ トワーク効果をさらに発揮させる観点から, 敦賀での乗換による旅客利便性の低下を回避することが求められるが, その 対応についてJR西日本や関係地方自治体の意向を確認する。
} 
体の要望書としては, 貸付料の活用や公共事業費 の拡充・重点配分など, 幅広い観点から早期に十 分な財源の確保を図り，既着工区間の早期完成を 図るとともに，北陸新幹線の未着工区間（敦賀〜 大阪間）についても整備方針を早期に明確化する ことなどが指摘されている。また, 地方公共団体 の設備費の負担を軽減するためにも，国家プロ ジェクトにふさわしい財源措置の拡充や制度を設 け，既着工区間の工事費増加分については，沿線 自治体への十分な説明とともに新たな負担が極力 生じないよう適切に対処することなども要望され ている。

特に, 並行在来線については, 地域住民の日常 生活に必要不可欠な交通手段であるとともに，重 要な貨物鉄道の広域ネットワークの一部を担って いることから，その維持・存続に向けては，地方 の負担軽減策や積極的な支援並びに新たな仕組み づくりを早急に実現することが必要であると述べ ている8。なお，表 1 は，整備新幹線に関わる主な 政府・与党申合せの経過をみたものである。

\section{（2）整備新幹線小委員会による試算の妥当性の確 認}

交通政策審議会陸上交通分科会鉄道部会整備新 幹線小委員会は，2012年 4 月 3 日に『整備新幹線 未着工区間の「収支採算性及び投資効果の確認」 に関するとりまとめ』を公表している9。ここでは 総括として,「北海道新幹線（新函館・札幌間）, 北陸新幹線（金沢・敦賀間）及び九州新幹線（長 崎ルート）（武雄温泉・長崎間）を新規着工するこ との収支採算性及び投資効果については, 前提と なる交通需要予測結果等を検討した結果, 国土交 通省が行った試算の妥当性が確認されたものと考
える。とし，分析結果の妥当性を確認している。 ただ，事業の実施に当たっては，収支採算性及び 投資効果に大きな影響を与える以下の事項につい て，数段の配慮が必要であるとも指摘している。 その第 1 は, 北陸新幹線と九州新幹線（長崎 ルート）については, 乗り換えの利便性を向上さ せるため, 既に基本的な走行性能が確認されてい る軌間可変電車を積極的に活用することが効果的 である。また, 北陸新幹線については, 新幹線区 間と関西方面・中京方面等の在来線との連絡輸送 量等を勘案し, 軌間可変電車以外の在来線列車と 新幹線の乗り換えの利便性向上にも十分配慮する ことが必要である。なお, 軌間可変電車について は, 今後も継続して, 走行耐久性や車両・線路の 保守性等を確認していくことが必要である。

第 2 は, 貨物列車と併用する北海道新幹線の青 函トンネル等の共用走行区間では, 安全確保の観 点から, 新幹線列車は, 当面, 時速 $140 \mathrm{~km}$ での運行 が予定されている。これについては，当該区間の 速度向上がもたらす効果に鑑みて, 今後, 積極的 に技術面の検討を行い, できる限り早い時期に速 度向上の見通しをつけることが極めて重要である。

第 3 は, 新幹線の総工事費については, 技術開 発等によって，これまでも節減の努力がなされて きたが, 今後も一層の努力を継続することが重要 である。また, 当該事業は長期化を要するプロジェ クトであることから, 事業評価については, 今後 の社会情勢や周辺環境等の変化を踏まえ, 最新の デー夕や条件を取り込み, 他の公共事業と同様, 継続的に点検を行うことが必要である。

上記の整備新幹線小委員会による配慮事項は, 新規着工する 3 線 3 区間の事業遂行上極めて重要 な指摘であり,こうした課題を一つずつクリアす

\footnotetext{
7 現在建設中の武雄温泉〜諫早間と新たな区間である諫早〜長崎間を，一体的な事業（佐世保線肥前山口·武雄温泉間の複 線化事業を含む。）として扱い，軌間可変電車方式（標準軌）により整備する。

8 並行在来線への維持·存続策としては, 運行形態のあり方の検討, 鉄道資産の無償譲渡若しくは収益性に基づいた譲渡価 格設定のルール化, 初期投資及び維持経費に対する助成措置, 税制上の優遇措置, 貸付料の活用など幅広い観点からの新 たな財源確保などを挙げている。

9 以下のURLを参照のこと。http://www.mlit.go.jp/common/000207255.pdf
} 
ることによって適正な公共事業が推進されるもの と考える。

\section{4. 整備新幹線の経済効果と地域に及ぼす 影響}

\section{（1）整備新幹線の経済効果の考察}

整備新幹線を整備するに当たっては，2009年12 月24日の「整備新幹線の整備に関する基本方針」 （整備新幹線問題検討会議決定）に基づき, 以下の 基本的な $5 つ の$ 条件を満たしていることを確認し た上で，着工することとしている。a．安定的な 財源見通しの確保， b . 収支採算性， c . 投資効 果, d. 営業主体である J Rの同意, e . 並行在 来線の経営分離についての沿線自治体の同意, な どである。

整備新幹線は新たに着工するたびに，「推進派」 と「慎重派」の意見が対立することが多々ある。 慎重派は，特に便益費用比率が低すぎるというこ とを指摘している。便益費用比率（B/C）とは, 事業を行うことによって得られる効果のうち, 正 確な計測が可能である移動時間短縮を数值化し, 工事費や維持管理費などで割った指標のことであ る。一般的には, 当該事業によって得られる投資 効果の妥当性を評価するために用いられる10。北 海道・北陸・九州の各整備新幹線における未着工 区間のB/Cはいずれもほぼ「1.1」と推計されてお り, 数值的にはかなり低い状況にある。この着手 決定時の算定值については疑問を呈する意見も見 受けられる11。

しかし，この数值には整備新幹線開業に伴う経
済的かつ社会的な開発効果や波及効果がほとんど 考慮されていない。確かに, 新幹線の整備による 直接的な便益は，通勤者や観光客といった利用者 の時間費用の減少である。だが，それだけに止ま らず新幹線の開通によって都市や地域の利便性が 向上することにより，企業立地の優位性及び定住 圈としての魅力が向上するものと見达まれる。こ の結果，周辺地域の土地の時価や家賃等が上昇し， 不動産を所有している人にも開発利益などの便益 がもたらされる12。さらに観光客が増大すること により，地域経済が活性化するという効果も見込 まれる。従って, 整備新幹線は総費用に対して 1.1 倍以上の便益が得られると考えられる。実際, 整 備新幹線のうち，すでに開業している東北新幹線 盛岡〜新青森間や九州新幹線の鹿児島ルートの状 況をみると, 新幹線の開発・波及効果は極めて大 きいということがいえよう ${ }^{13}$ 。

ここで一例として，北陸新幹線の長野〜金沢間 開業による経済波及効果を挙げてみる。新幹線の 建設・保有主体である鉄道建設・運輸施設整備支 援機構は, 北陸新幹線（長野～金沢間）事業につ いて，新幹線による輸送サービスの向上や沿線各 地における消費者活動の活発化やビジネスの効率 向上，設備投資の活性化，行動域の拡大による産 業立地の促進などが期待される結果，地域計量経 済モデルによる全国の波及効果は, 年間約 1,020 億 円（開業後10年目の効果額を推計）を上ると試算 している14。

なお， $\mathrm{B} / \mathrm{C}$ 算定結果には，新区間で使用する 車両がフル規格であるか, フリーゲージトレイン

10 便益費用比率を算定する際の便益項目は, 直接便益としての利用者便益（消費者余剩）と供給者便益（生産者者余剩）で ある。社会的余剩の概念については, 石井晴夫編著（1996）『現代の公益事業：規制緩和時代の課題と展望』NTT出版, pp.6〜13.を参照されたい。

11 朝日新聞「事業費，膨らむ恐れ：整備新幹線費用対効果に疑問符」2012年 6 月27日朝刊, p.8。

12 欧米では, 早くから外部経済効果としての開発利益の還元方策が制度として導入されている。詳しくは, 石井晴夫 (1999) 『交通ネットワークの公共政策 (第二版)』中央経済社，pp.81〜101.を参照されたい。

13 もちろん以下の問題点も考虑しなければならない。「間接効果として地域開発効果が強調されることがあるが，地域開発 効果を考える際には定量的には便益費用の二重計算を防ぐ必要がある。高速インフラの整備による時間短縮で利用者が得 た便益は，たとえば通勤や観光地への時間費用現象としてまず通勤者や観光客に帰着するが，つぎには便利になった土地 の地価・家賃・宿泊料の上昇となって不動産所有者・観光事業者に移転する。」(藤井弥太郎「投資効果」『交通新聞』2012 年10月29日)。 
(軌間可変電車)であるかによっても異なる。例え ば，北陸新幹線（金沢〜敦賀間）における $\mathrm{B} / \mathrm{C}$ フル規格では「1.0」であるのに対し，フリーゲー ジトレインでは「1.1」となっている15。

一方，収支採算性とは，整備新幹線の事業を開 始する前と後を比較して, 整備新幹線の営業主体 に生じる受益のことである。整備新幹線の営業主 体が管理する既設線（既設新幹線，既設在来線） の収支や, 並行在来線の経営分離前の収支も考慮 する。算定方法は, まず需要予測に基づき, 整備 新幹線や既設線にかかる収入・費用を算出し収益 を計算し, 整備新幹線事業を実施する前と後の収 益の差 (収支改善効果) を求める。そして開業後 30年間の収支改善効果（受益）を平均したものを, 収支採算性として算定するのである。図 2 は, 整 備新幹線の建設費用の財源スキームを示したもの である。

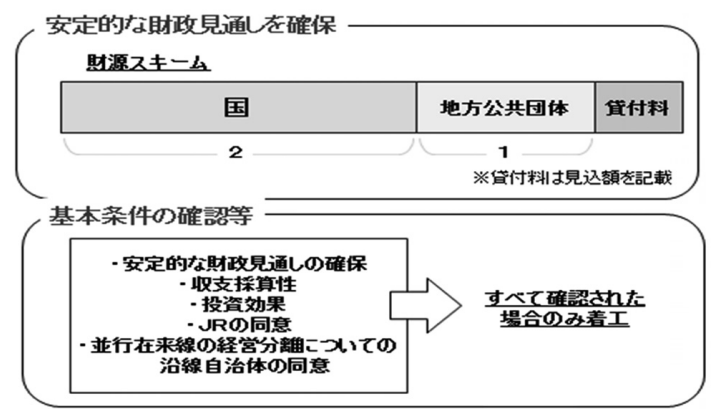

図 2 整備新幹線の建設費用の財源スキーム 出典）国土交通省の資料により作成。

\section{（2）災害時における整備新幹線のバイパス機能の 役割}

2012年 6 月に整備新幹線 3 区間の新規着工が決 定したことには，2011年 3 月の東日本大震災の影 響もあるものと考えられよう。周知のとおり, 大 震桨では東北および北関東の太平洋沿岸地域の鉄 道が大きな被害を受けた。もし仮に, 東京と大阪 という二大都市を結ぶ東海道新幹線が震災等で被
害を受ければ，日本経済に及ぼす影響は計り知れ ない。そこで, 東京と大阪を日本海側のルートで つなぐ北陸新幹線を早急に整備すべきだという声 が高まったのである。すなわち災害が多い日本と いう国の特性を踏まえて, このようなリスク管理 の観点からも, 全国的な新幹線交通網の整備は必 要であると考える。

2012年 3 月に鉄道建設・運輸施設整備支援機構 が取りまとめた『北陸新幹線 (長野・金沢間) 事業 に関する対応方針』では, 北陸新幹線の東海道新 幹線に対する代替機能の重要性を次のように明ら かにしている。「首都圈と中京圈, 関西圈を結ぶ東 海道新幹線は，この区間を往来する旅客輸送の 8 割以上を担っており, 年間輸送量は 1 億 3800 万人 (2010年), 日輸送量は38万人（2010年）を誇って いる。膨大な需要にこたえる高い輸送力と信頼性 は，まさしく日本経済の基軸である。しかしなが ら, 東海・東南海・南海地震による甚大な被害が 想定されており, 東海道新幹線が寸断された場合 の日本経済への衝撃は計り知れない。福井県の試 算によれば東西間幹線交通被害額は約 2 兆円にも 及ぶ。」と指摘している。このため, 東海道新幹線 の代替機能の整備が急務とされており，その役割 を担うのは日本海側の国土軸を形成する北陸新幹 線である。

また，大規模災害発生などにより，東海道新幹 線, 東海道本線, 中央本線, 東名高速道, 中央自 動車道といった東西間を結ぶ幹線交通網がストッ プした場合に, 北陸新幹線が東西間移動のどの程 度をカバーできるかを推定し, 北陸新幹線が担い 得る代替・補完機能を定量的に評価する調査も行 われている 16 。同調査では, 「中央防災会議東海地 震対策専門調査会報告書」(2003年 5 月28日) の想 定内容を基本とし, (1)東海地震発生により, 東海 道新幹線は当初 1 週間全線不通, 1 力月間は部分 折り返し運転，2東名高速道路および中央自動車

\footnotetext{
14 鉄道建設・運輸施設整備支援機構『北陸新幹線（長野～金沢間）事業に関する対応方針』2012年 3 月，p.44参照。

15 国土交通省鉄道局（2012）「投資効果及び収支採算性に関する詳細資料」p.63を参照のこと。

16 北陸経済連合会・関西経済連合会『北陸新幹線による東海道新幹線の代替補完機能評価』」2011年 8 月。
} 
道は当初 1 週間全線不通, 1 力月は緊急走行車両 のみ通行可能, (3)これらの想定に基づく間接被害 総額は約 2 兆円，(4)新幹線等の寸断による実質的 経済影響額は50億円/日(警戒宣言を行った場合に おける実質的な交通代替損失, 生産機会及び消費 機会損失額の合計額）と仮定している。

上記の推定の時点としては, 国土交通省「平成 17年度全国幹線旅客純流動調査」における流動量 と, 現時点における交通ネットワークを基準に, (1) 北陸新幹線が金沢まで延伸している，(2)敦賀まで 延伸している, (3)全線開通している, の各場合に おける迂回流動発生量を, 現在を基準に推定され ている。同調査のフローは, 図3のとおりである。

この調査の結果によると, 北陸新幹線迁回ルー 卜選択による回復流動量は, (1)金沢まで延伸して いる場合は, 約50千人/日（回復困難流動量の約 25\%)，(2)敦賀まで延伸している場合は, 約68千人 /日（回復困難流動量の約 $33 \%$ ), (3)全線が開通し

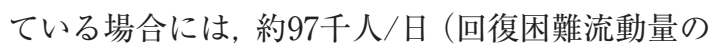
約 $50 \%$ ）と推計されている。

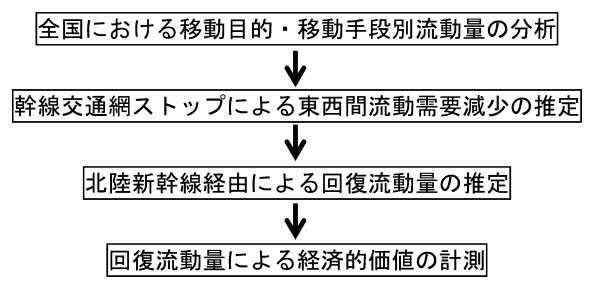

図 3 調查フロー

\section{5. 並行在来線問題とJR貨物の調整措置}

\section{(1) 並行在来線問題}

並行在来線とは，整備新幹線区間を並行する形 で運行する在来線の鉄道のことを指し, 新幹線の 開業によって並行して走る在来線の特急列車（優
等列車）などが新幹線に移る路線を意味している。 営業主体であるJRにとって, 整備新幹線に加えて 並行在来線を経営することは過重な負担となる場 合があり，沿線のすべての道府県及び市町村から 在来線の分離に関する同意を得た上で, 整備新幹 線の開業時にJRから経営分離されることとなっ ている ${ }^{17}$ 。経営分離される並行在来線区間は, 工 事実施計画認可前に沿線自治体及びJRの同意を 得て確定することになる ${ }^{18}$ 。なお, JRからの経営 分離後の並行在来線の多くは, 株式会社形態の第 三セクター会社により運営されている。

すでに開業している並行在来線としては, しな の鉄道, 肥薩おれんじ鉄道, 青い森鉄道, IGRい わて銀河鉄道などがある。いずれの並行在来線と も第三セクター会社として運営されているが, 観 光客や通過利用客など定期外旅客の減少, 利用者 の減少によるサービス価格の值上がりやそれに伴 うサービスの低下, 並行在来線運賃の值上げ, 地 域交通サービスの縮小など, さまざまな問題が顕 在化している。特に, 経営状況については, 多く の第三セクター会社で厳しい事業運営を強いられ ている19。

整備新幹線の開通により分離された並行在来線 は, その多くは不採算線区ではあるものの, 地域 住民の足として, また沿線地域の産業振興や観光, 住民福祉, 環境保全などの面で大きな貢献を果た している。つまり, 並行在来線は当該地域にとっ てかけがえのない財産であり, 必要不可欠の交通 手段と言えよう。同時に, 超高齢社会を迎えて, マイカー利用から並行在来線等の公共交通機関へ の転換は, 生活の安全面からも極めて重要である。 今後, 北陸新幹線については2014年度末の開業 予定に伴い, 信越本線（長野〜直江津間）及び北 陸本線（直江津～金沢間）がJRから経営分離され

\footnotetext{
17 新幹線の開業と同時に, 原則として並行在来線の経営はJRから分離される根拠は, 平成 2 年 12 月政府与党申合わせ及び 平成 8 年12月政府与党合意に基づいている。

18 これは, 1996年 (平成 8 年) の政府与党合意に基づくものである。

19 並行在来線として最初に開業したのは, 長野県のしなの鉄道である。同社の経営改革については, 以下の小論を参照され たい。石井晴夫 (2002)「しなの鉄道の経営改革と新幹線並行在来線問題」『運輸と経済』第62巻第 9 号, pp.20２8.
} 
る。すでに述べたように，並行在来線については， 地域住民のかけがえのない交通手段であるととも に，重要な貨物鉄道の広域ネットワークの一部を 担っていることを再認識しなければならない。以 上のことから, 並行在来線の維持・存続に向けて は，地方の負担軽減策や積極的な支援策など，新 たな仕組みづくりを早急に実現することが必要で ある。

\section{（2）JR貨物の線路使用料と調整措置}

前述のように，整備新幹線の開業に伴って並行 在来線がJRから経営分離されることとなるが, 経 営分離された並行在来線を運営する並行在来線の 運営・運行会社の経営環境は厳しいことから, 当 該路線を自社の旅客列車以外の貨物列車が走行す る場合，JR貨物の利用実態に応じた合理的水準 の線路使用料を第三セクターの鉄道会社または路 線所有者に対して確保することが必要である。そ の一方で, 苦しい経営が続くJR貨物についても, 線路使用料の新たな負担増は回避しなければなら ない。このことから, 差額相当分を「調整金」と して鉄道建設・運輸施設整備支援機構より JR貨物 に交付するスキームが導入されている(図 4 参照)。

その背景としては, JR貨物が支払う線路使用 料が並行在来線の第三セクター化後も従前どおり の水準に据え置かれれば, 鉄道貨物の輸送ネット ワークが寸断されないことや, JR貨物に受損が 生じないことなどの観点から, 調整制度の創設の 措置が講じられてきた。具体的には，2002年10月 の「全国新幹線鉄道整備法施行令」の改正により, 新幹線貸付料収入を原資とする「調整措置」が制 度化されたのである。また，2008年12月の「整備 新幹線に係る政府・与党ワーキンググループにお ける合意事項」により，貨物調整金について2009 年度から, 列車指令システム, 橋梁の架け替え, トンネルの改修・補修等の新規設備投資に係る資 本費が新たな対象経費として追加され，第三セク
ター鉄道会社に対する支援策が拡充された。

さらに，2011年には，列車キロにより按分して いた経費を「車両の走行距離」により按分するこ ととし，使用実態に応じた線路使用料を支払うこ ととしたほか, JRからの譲渡資産に係る資本費 を対象経費に追加するなど, 並行在来線事業者に 対する支援強化が図られた ${ }^{20}$ 。

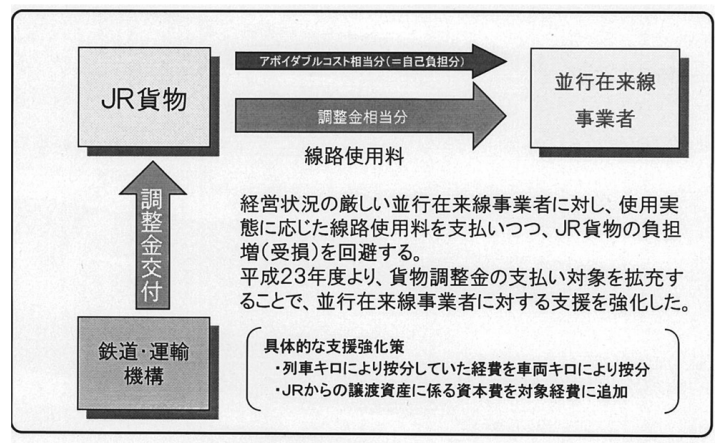

図 4 JR貨物における並行在来線への線路使用料 支払いスキーム

注) アボイダブルコスト相当額とは, 並行在来線が経営分 離に至る前にJR貨物がJR旅客会社に支払っていたと想定 される線路使用料をいう。

出典）国土交通省の資料を抜粋。

第三セクター等に支払う線路使用料は, 「調整措 置」の創設・拡充の際にさまざまな議論が行われ， 国・地方公共団体・第三セクター会社・JR貨物等 の関係者間で合意された配分基準に基づき適正に 計算されている。新ルールでは, 表 2 に示すよう に「列車走行に起因する経費」を“合理的な配分 基準”に基づいて客貨間で按分するもので, 客貨 両者にとって応分の負担となっている。

\section{6. 結びに代えて}

整備新幹線は, 地域間の移動時間を大幅に短縮 し, わが国のビジネスや観光の交流を促進するこ とで, 地域の産業や社会に大きなプラスの効果を もたらしている。こうした中で，2014年度末には 北陸新幹線が金沢まで延伸され，その後，敦賀ま

20 根拠法令についても, 2011年度の再拡充に伴い, 鉄道建設・運輸施設支援機構法が変更となった。 
表 $2 \mathrm{JR}$ 貨物が第三セクター等に支払う線路使用料の配分基準

\begin{tabular}{|c|c|}
\hline 列車走行に起因する経費 & 配分基準 \\
\hline レール、分岐器、道床等線路の修繥費、橋桁等の修繥費 & 換算車両キロ \\
\hline 除草、信号設備修繕・取替、駅ホームの修縉費 & 車両キロ \\
\hline トロリー線張替、付属設備の修繥費 & パンタキロ \\
\hline 維持管理に伴う人件費・業務費 & 修繥費比率 \\
\hline
\end{tabular}

で延長することが決定している。これにより，首 都圈〜北陸圈〜関西圈との所要時間は大幅に短縮 され，交流人口の増加が期待されている。こうし た北陸新幹線の整備効果を最大限生かしつつ, 地 域間の活性化を図るためには, 新幹線の各駅と国 内主要都市や観光地を結ぶ広域的な交通ネット ワークの整備を推進し, アクセス機能の向上を図 ることが求められている。

また，北海道新幹線についても2015年度末には 新函館まで延伸され，さらには札幌まで延長する ことが決定している。北海道新幹線の開通は, 東 海道・山陽・九州・上越・東北の各新幹線と相まっ て, 各圈域を結ぶ大規模な周回型の観光流動の発 生も予想される。こうした新幹線ネットワークの 機能が一段と高まる中で, 新幹線各駅の観光・地 域振興の拠点としての機能強化や, 首都圈 - 北陸 圈 - 関西圈 - 中京圈 - 東北南北圈 - 道南圈等との 経済・産業交流の活性化を図る取組みが喫緊の課 題となっている。

莫大な資金と労力を投入して誘致した整備新幹 線は，当該地域に新幹線駅ができただけでは，地 域の発展にはつながらない。地域・都市計画を しっかり形づくり，新幹線駅を核にした「新しい 街づくり」を進めなければならないのである。同 時に, 沿線のブランド価值を高めるためにも, 地 域開発効果を最大限発揮できる基盤（社会インフ ラ）整備が必要である。その意味においても, 地 域社会やそこに暮らす住民の日常生活に必要な交 通ネットワークの整備・充実も極めて重要な課題 であり，整備新幹線を“光”とすれば，並行在来 線問題は“影”の部分であるといえる。こうした 複合的な課題解決には, さまざまな関係者が協働 して取り組まなければならず，今こそ新しい発想
による高速交通ネットワークの構築を図ることが 求められている。

\section{<参考文献 $>$}

石井晴夫・金井昭典・石田直美（2008）『公民連携の経 営学』中央経済社。

石井晴夫（1999）『交通ネットワークの公共政策（第二 版)』中央経済社。

石井晴夫編著（1996）『現代の公益事業: 規制緩和時代 の課題と展望』NTT出版。

石井晴夫 (1995)『交通産業の多角化戦略』交通新聞社。 衛藤卓也監修, 大井尚司・後藤孝夫著 (2011)『交通経 済学入門』同文舘出版。

金本良嗣・山内弘隆編 (1995)『公的規制と産業(4)交通』

NTT出版。

国土交通省『国土交通白書』各年度版。

国土交通省鉄道局監修（2012）『数字で見る鉄道2012』 運輸政策研究機構。

日本交通学会編 (2011)『交通経済ハンドブック』白桃 書房。

塩見英治, 山崎朗編著 (2011)『人口減少下の制度改革 と地域政策』中央大学出版部。

竹内健蔵（2008）『交通経済学入門』有斐閣ブックス。 ティム・パウエル著, 岡野行秀・藤井弥太郎・ 小野芳

計監訳（2008）『交通の経済理論』NTT出版。

ティム・パウエル著, 岡野行秀・藤井弥太郎 - 小野芳

計監訳 (2007)『現代の交通システム:市場と政策』

NTT出版。

山内弘隆・竹内健蔵 (2002)『交通経済学』有斐閣アルマ。 国土交通省ホームページ http://www.mlit.go.jp/

tetudo/tetudo_fr1_000041.html

鉄道建設・運輸施設整備支援機構ホームページ

http://www.jrtt.go.jp/02Business/Construction/ const-seibi.html

北陸経済連合会ホームページ

http://www.hokkeiren.gr.jp/activity/houkoku/11080 3.html

その他, 関連のホームページ 